\title{
EMBLEMÁTICA E ICONOGRAFÍA VIRREINAL. \\ LAS APUESTAS DE DIEGO LEÓN PINELO Y \\ FRANCISCO DE ÁVILA (LIMA, SIGLO XVII) ${ }^{1}$
}

Javiera Carmona Jiménez(a)

VICEREGAL EMBLEMS AND ICONOGRAPHY. THE BET OF DIEGO LEÓN

PINELO AND FRANCISCO DE ÁVILA (LIMA, XVII CENTURY)

SIMBOLOGIA E ICONOGRAFIA VICE-REINAL. AS APOSTAS DE DIEGO

LEÓN PINELO E FRANCISCO DE ÁVILA (LIMA, SÉCULO XVII)

Fecha de recepción: 24 de noviembre del 2020

Fecha de aprobación: 15 de diciembre del 2020

Disponible en línea: 1 de enero del 2021

Sugerencia de citación:

Carmona Jiménez, J. (2021). Emblemática e iconografía virreinal. Las apuestas de Diego León Pinelo y Francisco De Ávila (Lima, siglo xvir). Razón Crítica, 10, 93-120. https://doi.org/10.21789/25007807.1712

$1 \quad$ El presente artículo se basa en un capítulo de la tesis titulada "Francisco de Ávila en la sociedad virreinal. Entre la autobiografía, el monumento y la memoria” presentada para obtener el grado de Doctora en Historia, Mención Etnohistoria en la Universidad de Chile, dirigida por Celia L. Cussen y evaluada por Carmen Bernand, Nancy van Deusen y Germán Morong. Las correcciones del texto se realizaron como parte del Proyecto de Investigación e Innovación Tecnológica (PAPIIT IG400619) "Religiosidad nativa, idolatría e instituciones eclesiásticas en los mundos ibéricos, época moderna" de la Universidad Nacional Autónoma de México (UNAM) y recogen los comentarios de la mesa "Emblemas, alegorías y otras imágenes del poder. Historias de éxito y fracaso", coordinada por Olaya Sanfuentes y Rafael Gaune en las xir Jornadas de Historia Colonial (Santiago de Chile, 2020).

(a) Javiera Carmona Jiménez

Doctora en Historia, Mención Etnohistoria Universidad de Chile

Profesora del Departamento de Ciencias de la Comunicación, Universidad de Playa Ancha, Chile javiera.carmona@upla.cl

https://orcid.org/0000-0002-5519-416X 


\section{R E S U M E N}

En el Virreinato del Perú la emblemática funcionó como un sistema intertextual que establece conexiones entre modelos de emblemas ya consagrados y el uso compartido de símbolos, frases latinas y composiciones que dialogan, pero también se oponen y divergen de las tradiciones simbólicas occidentales. El Hypomnema apologeticum pro Academia Limensi, del jurista Diego León Pinelo (1608-1671), y el Tratado de los Evangelios, del extirpador de idolatrías y canónigo de la Catedral de Lima, Francisco de Ávila (1573-1647), ambos publicados en Lima en 1648, poseen cada uno anteportadas que se analizan centradas en el conjunto visual conformado por imágenes alegóricas, emblemas y sus contextos de producción. La retórica visual virreinal revela que no solo se orientó a exaltar el poder y política monárquica y contrarreformista, sino también a desarrollar la afirmación identitaria de los autores contratantes de los grabados. Paradójicamente, ambas imágenes pueden ser vistas como un fracaso en distintos niveles, pero también como el triunfo en la lucha simbólica que implica toda afirmación identitaria que se realiza al quedar fijada en la memoria su retórica verbo-visual que no pocos podían descifrar.

PALABRAS CLAVE: emblemática; identidades coloniales memorias exitosas; pensamiento alegórico virreinal; retórica visual. 


\section{A B S T R A C T}

Emblematics in the Viceroyalty of Peru functioned as an intertextual system that established connections between models of emblems already consecrated and the shared use of symbols, Latin phrases and compositions that are related to - but also oppose and divert from- Western symbolic traditions. Hypomnema apologeticum pro Academia Limensi, by jurist Diego León Pinelo (1608-1671), and Tratado de los Evangelios, by the slayer of idolatries and Canon of the Cathedral of Lima, Francisco de Ávila (1573-1647), both published in Lima in 1648, had each front covers that are analyzed based on the visual set they incorporate, which is made up of allegorical images and emblems, and their contexts of production. The vice-regal visual rhetoric reveals that it was not only aimed at exalting monarchical and counterreformist power and politics, but also at developing the identity of the artists in charge of the engravings. Paradoxically, both images can be considered as a failure on different levels, but also as a triumph within the symbolic struggle of every affirmation of identity whose verb-visual rhetoric remains fixed in memories that many people could decipher.

\section{KEYWORDS: Emblematics; colonial identities; successful memories.}

\section{R E S U M O}

No vice-reino do Peru, a emblemática funcionou como um sistema intertextual que estabelece conexões entre modelos de emblemas já consagrados e o uso compartilhado de símbolos, frases latinas e composições que dialogam e, ao mesmo tempo, se opõem e divergem das tradições simbólicas ocidentais. O Hypomnema apologeticum pro Academia Limensi, do jurista Diego León Pinelo (1608-1671), e o Tratado dos Evangelhos, do extirpador de idolatrias e cônego da Catedral de Lima, Francisco de Ávila (1573-1647), ambos publicados em Lima em 1648, possuem cada um contracapas que são analisadas com foco no conjunto visual conformado por imagens alegóricas e emblemas e seus contextos de produção. A retórica visual vicereinal revela que não somente se orientou a exaltar o poder e a política monárquica e contrarreformista, mas também a desenvolver a afirmação identitária dos autores contratantes das gravuras. Paradoxalmente, ambas as imagens podem ser vistas como um fracasso em diferentes níveis e, paralelamente, como o triunfo na luta simbólica que implica toda afirmação identitária que se realiza ao ficar fixada na memória sua retórica verbo-visual que apenas poucos podiam decifrar.

PALAVRAS-CHAVE: emblemática; identidades coloniais; memórias bem-sucedidas; pensamento alegórico vice-reinal; retórica visual. 


\section{N T R O D U C C I Ó N}

En 1648 se publicaron en Lima, de manera simultánea, el Hypomnema apologeticum pro Academia Limensi, escrito por el jurista Diego León Pinelo, y el Tratado de los Evangelios, compuesto por el extirpador de idolatrías y canónigo de la Catedral de Lima, Francisco de Ávila. Ambas obras pertenecen al reducido conjunto de libros impresos en la primera mitad del siglo XVII en Lima que cuentan con elaborados grabados calcográficos acompañados de emblemas y anagramas. Estas imágenes impresas, de fuerte expresión simbólica, delatan el modo en que la doctrina de la analogía europea fue asumida de forma sistemática y generalizada por la sociedad virreinal.

Junto a los murales y pinturas, cientos de textos editados en los virreinatos durante el período colonial fueron las fuentes que dieron forma al universo simbólico característico de estas sociedades, entre ellas las relaciones festivas de profundo carácter emblemático. El pensamiento alegórico se erigió en Lima como un saber constituido tempranamente, reconocible en los primeros impresos del siglo xvI, como revela la sutil simbología renacentista que ilustra la doctrina cristiana (1583).

Desde mediados del siglo Xvi hasta fines del XviıI, la propaganda imperial fue el contexto de recepción de la emblemática en los virreinatos, de manera que la atribución de contenido ideológico centrado en la exaltación de la monarquía hispana se realizó a través de decoraciones efímeras y jeroglíficos pintados, luego reproducidos en estampas que ilustraron las relaciones festivas. La literatura festiva virreinal abarcó exequias, juras regias y entrada de virreyes, incluyendo además las descripciones de los jeroglíficos no grabados, ligados a celebraciones reales con composiciones laudatorias para virreyes, arzobispos, obispos, nobles, 
representantes de la corona y miembros de los grupos de poder colonial. En términos generales, la emblemática tuvo por contexto y significado la exaltación del poder de los reyes hispanos, imbricado con la defensa del catolicismo, lo que permite sostener que durante toda su existencia en los virreinatos la emblemática consistió en una retórica visual al servicio de la imagen del poder (Mínguez, 2017).

A diferencia de la Nueva España, durante la primera mitad del siglo XVII fueron escasos los libros con imágenes elaboradas en los talleres limeños. Las imprentas de la Ciudad de los Reyes participaban del vigoroso comercio de estampas religiosas provenientes de Europa, y si bien reprodujeron en sus talleres los modelos flamenco y alemán predominantes en el siglo xviI, en las portadas de la mayoría de los libros impresos en Lima en este período predominó el elemento tipográfico por sobre el ilustrativo, rasgo característico de los libros del siglo anterior (Pardo, 1990). Las cenefas, orlas, escudos de armas, monogramas de congregaciones religiosas, viñetas decorativas con motivos religiosos y letras capital adornadas con figuras paganas renacentistas, son los grabados empleados habitualmente por las imprentas limeñas en las primeras décadas del siglo xvir. En este período, la iconografía religiosa que expresa lealtad y fidelidad a la Corona es de pequeño formato, elaborada habitualmente en entalladuras de madera, con trazos sencillos, en contraste con la producción impresa europea en la que desde fines del siglo Xvi se relevó la xilografía por la calcografía, grabado en hueco sobre láminas de cobre (Pardo, 1990), innovación que permitía explorar con motivos diversos.

Al final del siglo xvir y durante el Xviı se afianzan en Lima las técnicas calcográficas, y la iconografía — que admite mayor variedad de motivos que ya no son solo religiosos-, se vuelve protagónica en las portadas de los libros impresos. Extendidos en todo el espacio de la hoja, los "frontis" o frontispicios y diseños de carácter arquitectónico grabados en metal, consolidan en Lima una corriente estética ya desarrollada en la Península a lo largo de todo el siglo xvir, considerada la "etapa barroca" de la portada del libro español (Reyes, 2010). Sin embargo, coexisten con los frontispicios las portadas con imágenes síntesis que exigen un esfuerzo hermenéutico en tanto la imagen es asistida por una indicación concisa y elíptica, amplificada en un discurso interpretativo (Ledda, 1996). A esta tendencia pertenecerían los grabados que anteceden a las portadas del Hypomnema apologeticum de Diego León Pinelo, y el Tratado de los Evangelios de Francisco de Ávila. 
Los estudios sobre el grabado colonial limeño se han centrado en el último tercio del siglo XVII y todo el siglo XVIII, atendiendo a las técnicas, creadores y motivos (Estabridis, 2002). Asimismo, se ha desarrollado la identificación de las correspondencias entre el grabado europeo y la pintura colonial, donde las estampas funcionaron como fuente original que inspiró murales y cuadros (Gisbert, 1980; Ojeda, 2014). Dentro de esta tendencia, son escuetas las menciones sobre la producción de grabados limeños en la primera mitad del siglo xviI, cuando afloran las posibilidades de desarrollo tecnológico de las imprentas, aumentan los artistas y artesanos, el mercado de las estampas cobra cada vez mayor vigor y se acrecienta la inclinación de los autores de libros por ilustrar sus obras con alegorías.

Otro rasgo del uso de emblemas en la primera mitad del siglo XviI en Lima consiste en la capacidad de algunos sujetos para emplear la retórica visual que encarna la emblemática en función de sus intereses personales, y subordinar a ellos la acostumbrada exaltación y promoción de la imagen de poder de la monarquía. Se trata de grabados cifrados que ponen de manifiesto la lucha simbólica implicada en la afirmación identitaria de los "mandantes" o contratantes, como autores de los impresos en los que aparecen las imágenes. La trayectoria de los letrados Diego León Pinelo y Francisco de Ávila sin duda encarna la parábola del éxito colonial, si se considera que el primero ocupó importantes puestos en la estructura de poder virreinal siendo judeoconverso, y el segundo logró ascender al nivel más elevado de la jerarquía eclesiástica sin contar con linaje y rebatiendo a lo largo de su vida la presunción sobre su posible condición mestiza. Pese a sus biografías llenas de logros, los emblemas de sendas publicaciones, en cuanto elementos simbólicos de las estrategias de autorrepresentación individual, permiten interrogar sobre la realización del triunfo de la memoria como resultado de la lucha simbólica que implica toda afirmación identitaria. Cabe interrogarse sobre la fortuna de estos emblemas (o sus derrotas) en la fijación o anclaje necesario para el reconocimiento identitario en las culturas impresas limeñas de mediados del siglo XVII, así como en relación con la articulación del plano de la subjetividad con las memorias coloniales colectivas o "corporativas". En el presente artículo se analizan y confrontar los emblemas y el sentido alegórico de las imágenes de los grabados del Hypomnema apologeticum pro Academia Limensi de Diego León Pinelo y del Tratado de los Evangelios de Francisco de Ávila. El objetivo es comprender las articulaciones de las agendas individuales de los sujetos históricos con la política monárquica 
y contrarreformista a través de las imágenes y emblemas que cumplen la función de presentar el lugar desde el que sitúa el autor en el entramado del poder colonial y que proporcionan la clave de lectura de sus respectivas obras.

En el análisis se establecen las condiciones de producción de los dos libros como contexto de los paratextos (dedicatorias, aprobaciones apologéticas, prefacio, etc.), los que exponen la "interautorialidad" de las obras (Gutiérrez, 2002) en tanto dejan entrever aspectos de las condiciones sociohistóricas de la creación, producción y aspiraciones de circulación de los libros. Se interpreta la simbología de los grabados y se establece la correspondencia entre los tópicos y motivos de los discursos de ambos autores que permiten fijar el sentido de los emblemas e imágenes alegóricas de sus anteportadas.

\section{LA ALEGORÍA DEL SABER Y LA DEL INGENIO INDIANO}

En el conjunto de los primeros libros impresos en Lima en el siglo Xvi cabe destacar el único ensayo de frontispicio hecho en la Ciudad de los Reyes en esta época. Se trata del Praecepta grammatices ex variis collecta auctoribus del fraile agustino granadino Julián Martel, impreso en 1594. El libro es una rareza en tanto es la única portada limeña de tono arquitectónico del siglo Xvi (Pardo, 1990) y de buena parte del Xvir si se considera que la eclosión de este motivo barroco fue en el siglo xviri. Hecha a partir de una entalladura de madera rústica, la Praecepta grammatices responde a la estética "a la romana" que caracterizaría la producción impresa del taller limeño de Antonio Ricardo en el siglo Xvi (Estabridis, 2002). En su esquema arquitectónico se desarrolla el rico contenido alegórico de la gramática como un jardín, motivo visto en la pintura renacentista (Stastny, 1984). Las enredaderas trepan por las columnas que forman un pórtico o puerta en dirección al texto, en alusión a la prolongada tradición literaria de la Antigüedad que sugiere la jardinería espiritual de la educación universitaria, particularmente de la gramática. El par de columnas corintias soportan cada una en su parte superior las urnas flameantes que simbolizan la divinidad, y que flanquean una luneta decorada por follaje y flores (figura 1). 
Figura 1. Portada de la Praecepta grammatices

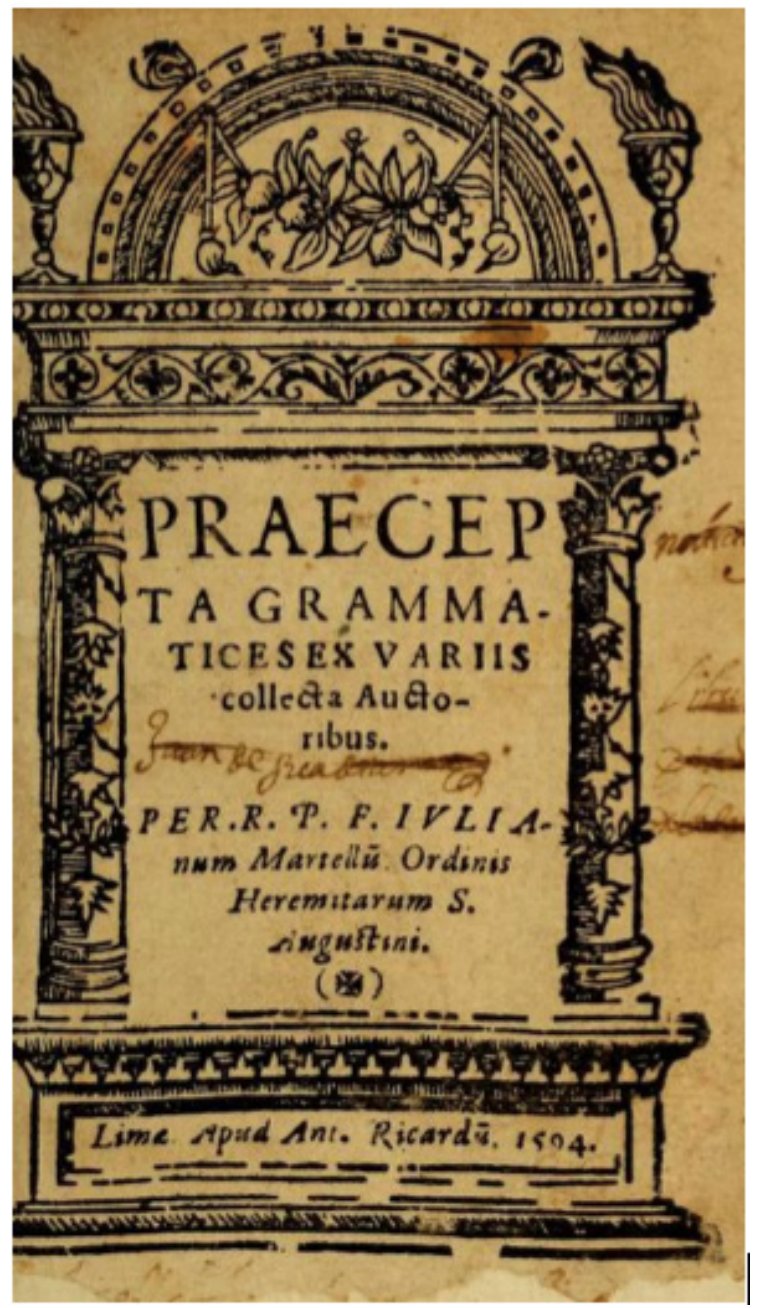

Fuente: Martel (1594).

Con autorización y elogio del virrey García Hurtado de Mendoza, Marqués de Cañete, por considerarlo "útil y provechoso para mandarlo a imprimir" (Martel, 1594), el compendio de gramática latina de Martel tuvo por finalidad evitar entre los estudiantes agustinos la corrupción de los contenidos originales en el "traslado" descuidado desde múltiples fuentes hacia los cartapacios. Martel intentaba con su obra revertir el método de estudio basado en la anotación personal en un cuaderno, estrategia promovida por numerosos autores del humanismo renacentista bajo la teoría de la imitación o copia, como ejercicio previo a la génesis del discurso personal. Sin embargo, en el apartado final de la Praecepta 
grammatices, Martel presenta un repertorio de sentencias latinas traducidas al español para utilizar en la prédica, en una suerte de compilación de frases, florilegios y poliantheas (llamadas también jardines o huertos), práctica también de raigambre renacentista que fragmenta y conquista el discurso ajeno para la creación y fijación de un discurso individual enérgico (Nakládalová, 2012). Así, la imagen de la portada de la Praecepta grammatices expone la adecuación del acto enunciativo que desarrolla al interior del libro de gramática latina con el gráfico figurativo del frontispicio, con lo que da lugar a una paradójica combinación de cambio en la aparente continuidad del ideal de erudición colonial. Martel crea su fuente única acudiendo a variadas obras como fuentes, para luego organizarlas en una fórmula basada en la obtención de la copia, acción complementaria al ejercicio de la retórica que sortea el estilo tedioso.

En su rol de prior, habiendo sido maestro de novicios, Martel intenta corregir la dispersión del método de estudio de los discípulos agustinos y se revela como un humanista que comparte tempranamente en Lima el pensamiento alegórico europeo que se extenderá a lo largo del siglo XVII, adhesión del fraile manifiesta desde "la puerta de entrada" de su obra pedagógica hacia un jardín de sabiduría latina formado de conceptos y formas breves predicables.

En la cultura impresa limeña de fines del siglo xvi, la Praecepta grammatices puede considerarse indicio del comienzo del uso de los procedimientos característicos de la economía significante en que el emblema pertenece al sistema comunicativo basado en el pensamiento alegórico de occidente. A lo largo del siglo xvir se expande la función del emblema y las imágenes alegóricas, particularmente en los textos didácticos, religiosos y persuasivos.

Así, la simbología del vergel del claustro académico permanece hasta en las Constituciones de la Universidad de San Marcos de 1735, donde se observa nuevamente el motivo hortelano renacentista relacionado con la actividad universitaria, visto incluso en la iconografía de la pintura mural cuzqueña de invención local entre 1770 y 1773 (Stastny, 1984). Dentro de esta tradición, el Hypomnema apologeticum pro regali Academia Limensi in Lipsianam periodum ${ }^{1}$, de Diego León Pinelo, es un ejercicio retórico que

1 La edición castellana fue traducida del latín por Luis Antonio Eguiguren en 1949 y se titula "Semblanzas de la Universidad de San Marcos". Lima: Talleres de la Empresa Gráfica T. Scheuch. El título completo es "Alegato Apologético en defensa de la Universidad límense para la controversia lipsiana. Dirigido a la Real Audiencia de Lima; a los oficiales reales y a los oidores en particular. Agréganse disertacioncillas gimnástico paléstricas, canónico legales o mixtas, en parte 
se aparta de la herencia simbólica europea que concibe el jardín como el espacio del logos y el pensamiento, y emplea una expresión simbólica con referentes coloniales que anticipa el punto de vista del letrado desarrollado a lo largo del libro.

En 1647, León Pinelo obtiene la cátedra de Prima de Cánones en la Universidad de San Marco y escribe el Hypomnema apologeticum como apología del claustro limeño y refutación al Lovanium (1605) del filósofo humanista belga Justo Lipsio, quien omitió la academia limeña al repasar las más dignas y admirables del mundo puesto que en los Reinos de las Indias solo habría barbarie. En esta obra histórica sobre la ciudad de Lovaina y su universidad, Lipsio comparte la visión dominante europea en que los españoles habrían llevado la cultura y la religión a un continente bárbaro, salvaje y supersticioso mientras elogia y defiende a la monarquía hispana al cumplir su misión civilizadora. La respuesta de León Pinelo en el Hypomnema apologeticum intenta igualar a Lipsio - a quien realmente admiraba- no solo en referencias eruditas, sino haciendo gala del conocimiento profundo de la obra filosófica y política del humanista belga. Asimismo, León Pinelo aporta con un informe sobre la estructura y funcionamiento de la Universidad de San Marco no solo equiparable a la descripción del claustro belga, sino desarrollando con creces una tesis dotada de base científica, lo que dejaría al descubierto lo artificioso de la maniobra apologética de León Pinelo (Papy, 2001). La defensa idealizada de la identidad intelectual del Nuevo Mundo sería una alabanza de sí mismo como parte de una estrategia de promoción personal de León Pinelo para fortalecer su posición en la Universidad de San Marcos, fundamento de la disputa "póstuma” con Lipsio, quien murió en 1606 (Gerbi, 1945).

Entre las motivaciones de León Pinelo para publicar el Hypomnema apologeticum se cuenta la necesidad de mitigar el ascendente judío de su familia, obstáculo para el desarrollo de su carrera profesional. El informe preparado por la Inquisición de Lima el 9 de julio de 1647 al momento de obtener la cátedra de Prima de Cánones, advierte del peligro de "fiar la interpretación de sagrados cánones y materias eclesiásticas y de sacramentos a persona de raíz tan infecta y sospechosa por sí” (Medina,

extemporáneas, pulidas y útiles, como ellas lo atestiguarán. Autor el Dr. D. Diego de León Pinelo, antes catedrático de vísperas y en la actualidad de prima de derecho canónico en la florentísima Academia de San Marcos, y abogado en la cancillería de los Reyes. Lima, Oficina de Julián de los Santos $\gamma$ Saldaña. Año del Señor de 1648". 
1904, p. 391). En Lima era conocida la muerte en la hoguera de sus abuelos paternos y maternos en Lisboa debido a su judaísmo, así como la migración ilegal de su padre Diego López León al Nuevo Mundo (Tardieu, 1995). Sin embargo, pese a ser judeoconverso su padre se volvió sacerdote en edad madura y fue nombrado en 1628 confesor y administrador del arzobispo de Charcas, Fernando Arias de Ugarte, contando con la confianza y protección del prelado. En 1636, Diego León Pinelo asumió la cátedra de Víspera de Cánones, y ya era abogado de la Real Audiencia, asesor de la curia de Lima y de algunas órdenes religiosas, mientras que sus hermanos mayores también obtenían reconocimiento social e intelectual en el Virreinato del Perú. De manera que la condición de nuevos cristianos de la familia León Pinelo no parecía una dificultad tan poderosa que impidiera el desarrollo de estos letrados en el círculo criollo de la sociedad colonial. Incluso, a pesar de las suspicacias derivadas del auto de fe de 1639 a propósito de la presunta "gran complicidad" judeoportuguesa contra la monarquía hispana en Lima puesto que a contar de 1642 se redujeron notoriamente las causas judaizantes en Lima hasta extinguirse en 1655 las que comprometían a los portugueses (Ramos, 1988). En 1656 Diego León Pinelo fue nombrado Protector General de los Naturales de la Real Audiencia de Lima y también rector de la Universidad de San Marcos hasta 1658, contando con poderosos vínculos con el virrey Pedro de Toledo y Leyva, Marqués de Mancera, y con el arzobispo Pedro de Villagómez (Rose, 1998). En 1668 León Pinelo fue asesor general del virrey Pedro Fernández de Castro, Conde de Lemos, entre los nombramientos que recibió en su vida.

Invalidado el temor a la Inquisición en Lima y el distanciamiento de su antecedente judaizante entre las motivaciones para escribir el Hypomnema apologeticum, la reivindicación del "espíritu criollo" recupera verosimilitud y cabe precisar que al realzar León Pinelo los méritos intelectuales de la sociedad criolla excluye de manera explícita a los indígenas del presente, mientras que considera como un tiempo oscuro el pasado precolombino de barbarie. Desde este punto de vista, León Pinelo argumenta que las capacidades intelectuales de los criollos erradicaron la barbarie anterior de los indios (Rose, 1998). De hecho, en el capítulo vi del Hypomnema apologeticum establece la equivalencia entre los bárbaros y los indios al referirse a la cátedra de lengua general pues los eclesiásticos a cargo "de los indios en los suburbios y en los pequeños pueblos no ignoren la lengua de los indios, ya que el cuidado único de aquellos es conducir al eterno puerto del cielo a las gentes bárbaras, que ya han 
profesado nuestra fe"2 (León, 1648, párr. 19). Visto así, se trataría de una concepción de lo criollo que prescinde del componente indígena y por tanto desecha el mestizaje al considerar como criollos exclusivamente a los nacidos en el Nuevo Mundo, descendientes europeos. De modo que la reivindicación de la identidad cultural e intelectual criolla se remite a este grupo educado en la Universidad de San Marcos, igualada con la Universidad de Salamanca donde el mismo Diego León Pinelo se formó.

La escritura del Hypomnema apologeticum indica la existencia de un público en Lima sensible a la "cuestión criolla" definida en los términos que establece Diego León Pinelo, quien no usa el concepto "criollo" ni "peruano" y emplea la noción de "Nuevo Orbe" y "los ingenios de Indias" (ingenia colunt Indica) (León, 1648, párr. 45) a propósito de la semblanza de la Universidad de San Marcos. Dentro de esta audiencia general, se cuenta un grupo de poder muy preciso conformado por los miembros de la Real Audiencia, los oficiales reales y los oidores en particular, a quienes el autor dedica su obra (León, 1648). En varias oportunidades, entre 1647 hasta 1667, sucesivos virreyes fracasaron al proponer a Diego León Pinelo para una plaza como oidor, destacando sus consejos a la Corona, su prudencia y mucho saber (Rodríguez, 1992). De manera que el Hypomnema apologeticum se inscribe en una estrategia de concientización y obtención de apoyo de los miembros de la administración de la justicia colonial en los territorios de la monarquía hispana con la expectativa de un eventual nombramiento. Así, la redacción en latín del Hypomnema apologeticum no solo le permitió a León Pinelo demostrar y alardear sobre su preparación. El uso del latín apelaba a una minoría culta, pero de amplio alcance geográfico, con lo que garantizaba la lectura de la obra en la Península y en el resto de Europa, particularmente de la élite del poder monárquico que decidía sobre los cargos en los Reinos de las Indias. Además, los grandes movimientos intelectuales de la época (Reforma, Contrarreforma, Revolución científica, grandes descubrimientos) estaban bien representados en las traducciones al latín, incluso hasta la Ilustración, y no responde tan solo al gusto del momento dado que las traducciones al latín estuvieron mediadas por la capacidad de algunos individuos para convertir sus intereses personales en publicaciones (Burke, 2010).

2 Qui in suburbijs, E minotibus populis spiritali saluti prospiciunt Beneficiati Doftores: quorum haec vna cura est, ad aeviternum Coeli portum barbaras antea gentes iam Fidei sancta nostrae profesores ducere. 
León Pinelo evoca y elogia a la monarquía hispana cuando subraya el título de "real" que posee la Universidad de San Marcos; dotada, favorecida y engrandecida desde Carlos v hasta el presente (Felipe IV), sin dejar de señalar además la autorización pontificia de Pío v (León, 1648, párr. 43). Pero de una manera más sutil y perspicaz, el autor expone su posición política al subrayar que los graduados realizan el juramento de creer y enseñar el misterio de la Inmaculada Concepción de la Virgen María, cumpliendo con la octava de las nuevas constituciones de la Universidad de San Marcos. En el capítulo x de la Hypomnema apologeticum, acomete la defensa de la posición inmaculista en la controversia originada en Castilla e instalada por la Casa de Austria en el imaginario colectivo de los Reinos de las Indias como aglutinante místico en tanto se le consideró abogada especial de la monarquía. En la arena política, las órdenes religiosas tomaron posiciones difundidas a través de sermones impresos y en la prédica, enfrentándose entre sí por la Inmaculada Concepción. Los dominicos se opusieron a la doctrina sobre la concepción de María sin mancha de pecado, tesis defendida por el resto de las congregaciones, encabezadas por jesuitas y franciscanos. En esta contienda peninsular de los últimos años del reinado de Felipe iv los dominicos fueron derrotados simbólicamente y desplazados de los centros de poder (corte, universidades), aunque el dogma fue proclamado en 1854. Las sociedades virreinales también se abanderizaron y los letrados difundieron sus posturas a través de las aprobaciones de las publicaciones, sonetos y décimas incorporadas en discursos de tono universitario. De manera que el enaltecimiento que León Pinelo realiza de la Universidad de San Marcos es por su saber y su lealtad a la monarquía de los Habsburgo expresada en la fidelidad a la devoción mariana inmaculista, tópicos que convergerían en el argumento persuasivo sobre su propio talento para convertirse en oidor por sobre cualquier valoración intrínseca de la "cultura criolla".

En el opúsculo de Diego León Pinelo la imagen alegórica de la anteportada inaugura la argumentación de manera señera al asumir la tipología de las medallas, con el emblema en una disposición central rodeado de elementos para interpretar (figura 2). El lienzo central del óvalo contiene junto a la alegoría del sol radiante sobre el futuro promisorio del Nuevo Mundo un disco con mares, islas y montañas, envuelto por un listón con un texto latino apologético que refuerza la imagen central: Novus Orbis quotidie maior (El Nuevo Mundo es mayor cada día). El listón se desenrolla hacia la parte superior del emblema en dirección al sol radiante con el texto: Hodie ómnibus orior quasi tu (Hoy me levanto por todos igual que tú). 
Figura 2. Anteportada del Hypomnema apologeticum

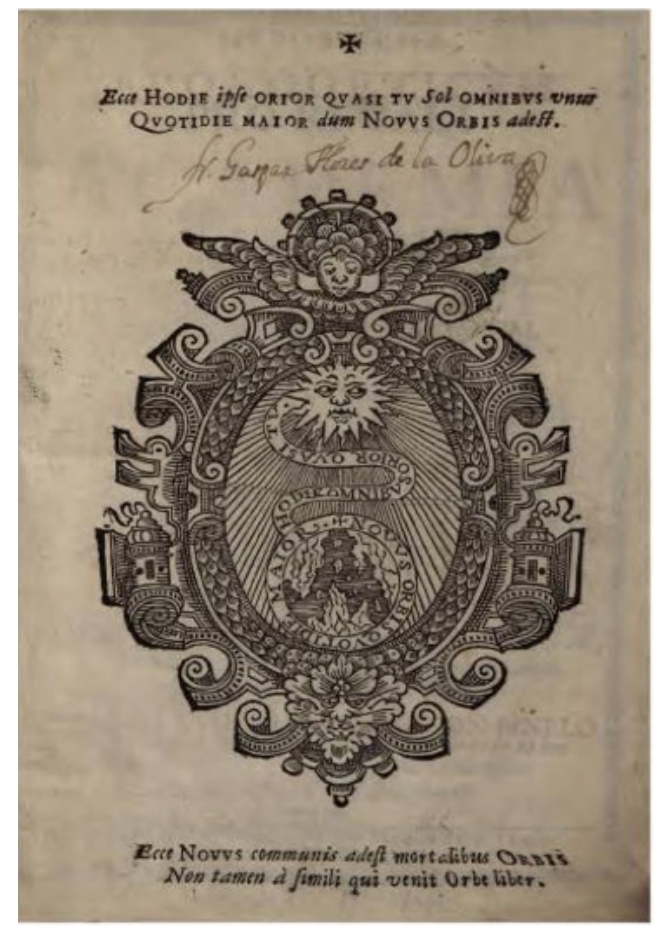

Fuente: León (1648).

La imagen de los rayos del sol encuentra su correspondencia al interior del texto cuando León Pinelo señala a los ingenios indianos formados en la Universidad de San Marcos, quienes "salen de aquí como caballos troyanos, como los rayos del sol, jueces relucientes, como rayos de la sabiduría, para que resplandezcan en todo el Nuevo Orbe por la guarda

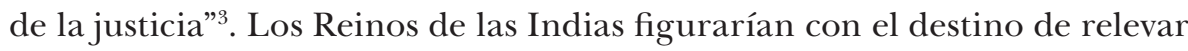
a la Península como poder imperial, lo que constituye un guiño a Lipsio quien recrea el topos del "curso natural" (naturae cursus) de Polibio sobre el desarrollo de occidente sobre oriente, como el sol de un nuevo imperio que surge (Papy, 2001).

Los dos dísticos repiten y refuerzan así el lema, el primero es casi textual y exhibe gestos tipográficos: Ecce HODIE ipse ORIOR QVASI TV Sol OMBIBVS unus / QUOTIDIE MAIOR dum NOVVS ORBIS adest. El que se puede interpretar como "Ved, hoy yo mismo me levanto como tú, un Sol para todos / mientras

3 Exeunt hinc, velut ex equo Troiano, judices relucetes, quasi á sapientiae radijs, quasi a Sole, vt in omnibus Novi huius Orbis partibus resplendeat custodita iustitia (Pinelo, 1648, párr. 26). 
el Nuevo Mundo luce más grande cada día”. El segundo dístico tiene el siguiente texto: Ecce NOVVS communis adest mortalibus ORBIS / Non tamen a simili qui venit Orbe liber. La frase latina se puede entender de la siguiente manera: "Ved, el Nuevo Mundo es presente común para todos los mortales / Sin embargo, no este libro que viene de un mundo similar".

Los dos emblemas que aparecen sobre y bajo la medalla indicarían una posición de exaltación de la cultura criolla (Gerbi, 1945). Sin embargo, cabe considerar dos planos en el foco de la argumentación, de manera que uno de ellos estaría en "los ingenios de las Indias" entendidos como los letrados, en particular los juristas formados en las universidades del Nuevo Mundo, que se asientan en las estructuras de poder colonial como "caballos de Troya", tal como aspira concretar el mismo Diego León Pinelo. El segundo plano se centra en la condición de Lipsio de convertido al catolicismo, lo que en el juego de equivalencias que establece León Pinelo es un elemento biográfico que nutre la concepción culturalmente ambivalente de los letrados "criollos" como resultado de la síntesis de la cultura europea afincada en el Nuevo Orbe y no con la tradición indígena que persiste.

\section{SAN PEDRO EPISCOPUS Y LA DEVOGIÓN DEL OBISPO DE INDIOS}

En los libros impresos en Lima durante el siglo XVII la portada suele ser la primera página, sin embargo, al igual que en el Hypomnema apologeticum de Diego León Pinelo, el monumental sermonario de Francisco de Ávila titulado Tratado de los Evangelios se inicia con un grabado que contiene un anagrama. En este caso es la figura de san Pedro la que ocupa toda la página como anteportada, a la que sigue la tradicional hoja con los datos de identificación de la obra o portada. La decisión de Diego León Pinelo y de Francisco de Ávila de inaugurar sus obras con una figura cifrada indica la voluntad de hacerla visible a través del discurso apologético en el primero, y por la palabra evangélica de los sermones en el segundo.

Dentro del conjunto de grabados de temas religiosos que circularon profusamente en Lima, en estampas destinadas a la devoción popular, la iconografía mariana prevalece por sobre cualquier otro tópico. En estampas como en libros impresos destinados a impulsar estos fervores en 
creciente difusión en el siglo XVII, se observa la instalación y desarrollo de la imagen de las vírgenes de la Inmaculada Concepción, la de Copacabana y Santa Rosa de Lima por sobre la de Cristo y los santos apóstoles.

La opción de Francisco de Ávila por la imagen de san Pedro para la anteportada del Tratado de los Evangelios señala una distancia con el registro visual mariano predominante en los impresos limeños religiosos políticos, escritos principalmente por autores agustinos, franciscanos y jesuitas. Ávila sitúa su sermonario en la tradición de la erudición bíblica en torno a la imagen de Cristo y los santos apóstoles, repertorio visual presente en la vida cotidiana limeña a través de esculturas, retablos de madera, platería, tapices y pinturas al óleo en altares, templos y capillas (públicas y privadas), así como en los abundantes impresos de vidas de santos y biblias ilustradas que alimentaron el mercado librero de la Ciudad de los Reyes. Las estampas flamencas fueron muy populares en el Virreinato del Perú, entre ellas las de los hermanos Wierix quienes trabajaron para la Compañía de Jesús proporcionando imágenes grabadas para ilustrar las obras impresas empleadas tanto en la formación de las élites como en las misiones evangelizadoras (Kubiak, 2008). Cabe recordar que Francisco de Ávila inició su educación en el Colegio Jesuita del Cuzco, una de las instituciones más elitistas del Virreinato, seguida por la universidad, configurando un enclave de cúpulas de poder económico y social, con afinidades políticas, estéticas y culturales que moldearon el gusto del eclesiástico por los libros, objetos científicos y estampas, entre otros.

Nacido en el Cuzco, de padres desconocidos, acaso mestizo, sin linaje, parientes, ni abolengo, Ávila fue acogido por una familia criolla cuzqueña de cierto rango que le proporcionó una educación de élite. En Lima ingresó a la Universidad de San Marcos y, finalmente, logró establecer relaciones sociales con los grupos de poder que le permitieron ascender en la jerarquía eclesiástica y social en una sociedad en apariencia muy rígida en su repartición entre castas y clases. Desde su rol como cura de indios, Ávila logró ascender hasta ubicarse en los cabildos eclesiásticos de La Plata y luego en Lima (Duviols, 1966; Acosta, 1987). En el Tratado de los Evangelios Ávila compendia sus sermones y también expone su trayectoria pastoral, la que se remonta a 1610 cuando condujo el auto de fe por el que fue nombrado "extirpador de idolatrías" iniciando la campaña de visitas eclesiásticas en las áreas rurales de la Arquidiócesis de Lima para erradicar las prácticas religiosas de los indios. A lo largo de su vida, Ávila acumuló un notable patrimonio integrado por propiedades y bienes diversos, como muebles, muchos libros, cuadros y estampas (Ávila, 1647). No obstante, 
el inventario de bienes del sacerdote cuzqueño no es lo suficientemente preciso en la información sobre las pinturas y grabados que poseyó, pero sí es claro que en su biblioteca tuvo libros bellamente ilustrados. Entre ellos se cuenta por ejemplo con las cartografías y mapas que revelaban rutas de navegación, y otros ornamentales con paisajes o escenas míticas e históricas, entre los que destacan el Theatrum orbis terrarum (1570) del flamenco Abraham Ortelius — señalado como el primer atlas moderno-, y el Cosmographicae (1585) de Gerhard Mercator (Hampe, 1993).

Las colecciones de estampas y libros con imágenes que los jesuitas usaron para sus actividades pedagógicas eran solicitadas en las imprentas por clientes acaudalados como Ávila, los que acudían a los talleres para contratar obras para cofradías, conventos, monasterios, hospitales, casas particulares e incluso ceremonias públicas como funerales, entradas de virreyes y arzobispos, entre otras. De este modo, las obras impresas como libros ilustrados y álbumes actuaron como soporte de los grabados flamencos que luego fueron modelos de grandes óleos y esculturas encargadas para ataviar las iglesias, universidades, colegios y viviendas.

El grabado de san Pedro en la anteportada del Tratado de los Evangelios tiene como punto de referencia insoslayable los repertorios de estampas flamencas que ofrecen una fértil iconografía en las series sobre los santos apóstoles, imágenes presentes de igual modo en las obras de talla y ensamblaje como retablos en capillas, retablos-sepulcros, portadas retablo, sillerías, púlpitos, cajonerías y otros muebles litúrgicos elaborados por excelsos maestros que en ocasiones rivalizaron entre sí.

Los grabados flamencos de san Pedro y María fueron imágenes dominantes en la cultura religiosa europea de los siglos XVI y XVII (Burke, 2001). Las diversas series de los doce apóstoles ofrecen las formas adoptadas en el arte colonial limeño en que se distingue a Pedro, llamado "Príncipe de los Apóstoles", del conjunto de discípulos de Jesús que él encabezó. La triple misión que se le encomendó a san Pedro se manifiesta en las representaciones del santo, como son el cuidado del rebaño, la mantención viva de la fe y la edificación sobre él de los muros de la futura Iglesia de Cristo. De hecho, el cambio del nombre primitivo Simón por Cefás (palabra aramea equivalente al latín petrus o "piedra") obedece a este último cometido. Cristo además prometió entregarle las llaves del Reino de los Cielos, concesión presente en la iconografía "pétrea” en un par de llaves: una de oro y otra de plata, para abrir el cielo y la tierra.

Pero el grabado de san Pedro en el sermonario de Ávila tiene como correlato narrativo la Leyenda dorada del dominico Santiago de la 
Vorágine (escrita hacia 1264), en la que se relata que san Pedro estando en Antioquía fue encarcelado por el gobernador Teófilo, y cuando se encontraba a punto de desfallecer en la cárcel recibió la visita de san Pablo quien le dijo que Teófilo le liberaría si conseguía resucitar a su hijo muerto hace tiempo. Ocurrido el milagro, san Pedro recobró su libertad y Antioquía entera quiso honrarlo con la construcción de una cátedra elevada para que todo el mundo pudiera verle y oírle. San Pedro ocupó la sede de Antioquía por siete años, al cabo de los cuales marchó a Roma para establecerse allí por otros veinticinco años.

En el grabado de la anteportada del Tratado de los Evangelios se observa a san Pedro ocupando su tribuna en Antioquía mientras sostiene en cada mano la llave y la Biblia. Al fondo se observa un fragmento de pared y a lo lejos la ciudad amurallada, en tanto la filacteria expone el inicio de "El Credo" (figura 3). En el repertorio de grabados flamencos de los siglos Xvi y XVII, la ilustración de la estadía de san Pedro en Antioquía es inusual.

La filacteria del grabado de san Pedro presenta la oración inicial de El Credo, seguida por el texto latino que aporta el contexto de la imagen: san Pedro en su rol de obispo, autoridad máxima de la Iglesia de Cristo que abarca los territorios que van desde Antioquía hasta Judea, prelado muerto de manera sangrienta por Nerón ${ }^{4}$. Hecho en buril, el grabado ofrece una ligazón con la concepción del retrato renacentista centrado en la figura de los cardenales (figura 3), composiciones del siglo Xvi en las que el fondo y ángulo agudo de la silla —y en ocasiones la mesa- convergieron para que la figura de papas o cardenales apareciera mayor de lo que realmente eran (Pope-Hannessy, 1985). Así se puede ver en los retratos grabados de Giulio de Médici (Clemente viI) realizado por Sebastiano del Piombo (s. XviI), y el anónimo de Giovanni de Médici o papa Leo x (s. Xv-xvi).

La expresión de san Pedro es severa y reservada, como acostumbran las autoridades de la Iglesia. Sin embargo, en la devota sociedad limeña en la que se desenvolvió Ávila, la posición de san Pedro casi de frente, con la cabeza girada tres cuartos hacia la derecha mirando al cielo y especialmente iluminada, resalta el halo de santidad del obispo. El tema de san Pedro Episcopus fue "inventado" por Joos van Winghe (1544-1603) artista flamenco pintor de la corte de Alessandro Farnesio en Bruselas,

\footnotetext{
4 S. Petrus Episcopus, Antiochenus, in Ponto, Rithy, Asia, Cappadocia, Caesarea, Joppe, Galatia et Judea docuit. à Nerone in cruem adact.

5 La inscripción en la parte inferior del grabado es Iodocus à Winghe inven, descifrado por el profesor Almerindo Ojeda y consignado en The Project on the Engraved Sources of Spanish Colonial Art (pessca).
} 
Figura 3. Anteportada del Tratado de los Evangelios

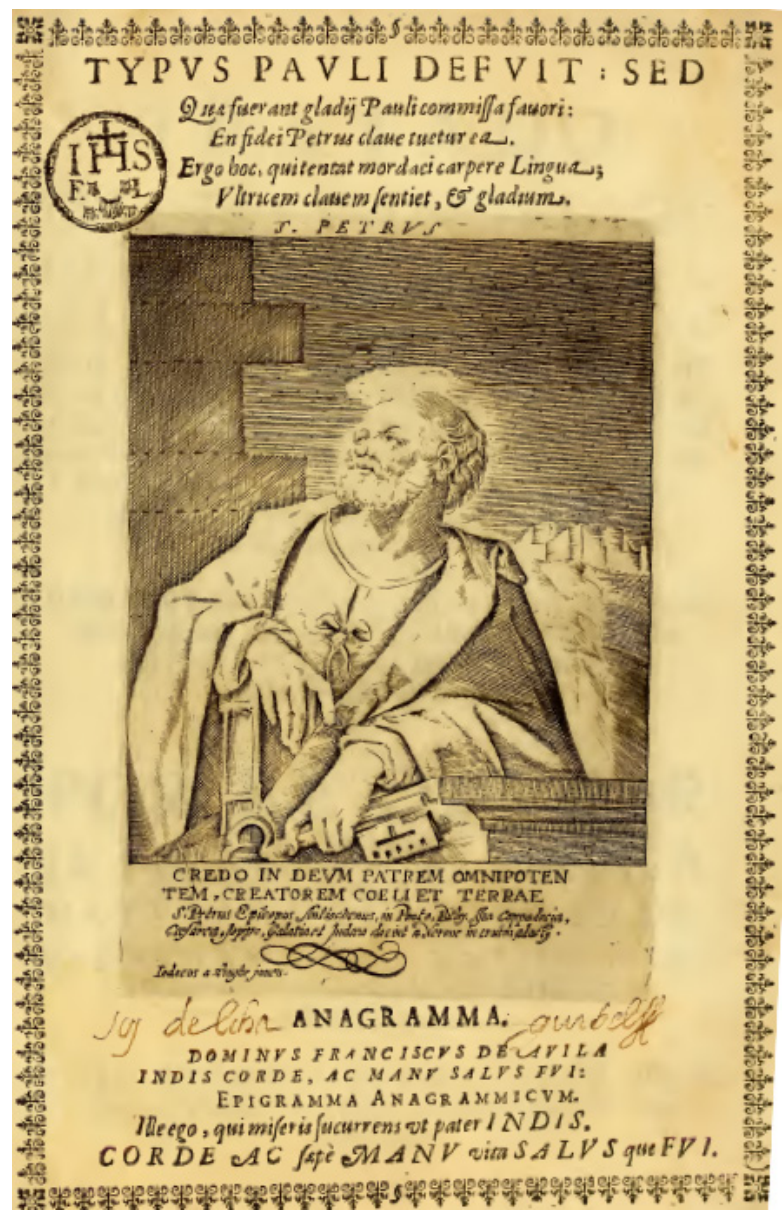

Fuente: Ávila (1648).

y el grabado anónimo de la anteportada podría haberse realizado en la imprenta de Pedro de Cabrera, de donde salió el libro.

Las inscripciones (epigrama y anagrama) diseñadas por Francisco de Ávila que acompañan al grabado limeño particularizan la composición aportando la descripción y significación de la experiencia del sacerdote cuzqueño al conjunto, en el que la imagen central corresponde a Petrus en su condición de apóstol devenido en autoridad de la Iglesia en el mundo terrenal, en lugar de su función celestial como santo. La imagen se encuentra fijada por dos textos latinos o "cintas parlantes", una en los bordes superior e inferior, las que aportan con la explicación de la alegoría y corresponden a epigramas, definidos como palabras (conceptos) 
que ilustran los objetos ${ }^{6}$. Esta práctica literaria helénica, actualizada en el ambiente neoplatónico italiano, muy difundida en el barroco español y desarrollada vigorosamente en los Reinos de las Indias a partir de la composición de breves y sutiles poemas, permitían a los autores hacer exhibición cortesana de su ingenio. Por tanto, se trató de un género cifrado, dirigido a grupos especialmente instruidos, capaces de penetrar en el juego de ingenio que ofrecen.

Bajo el mote de Typus Pauli defuit sed (Desaparecido el tipo de Paulo), el epigrama se refiere a la ausencia de san Pablo y la duda sobre quién asume la tarea de conversión de los gentiles, con lo que el emblema cumple la tradición cristiana de asociar a ambos apóstoles dado que ambos murieron en Roma, el mismo día y a la misma hora, y sobre ellos la Iglesia sustenta los pilares de su fe. La conversión de los gentiles asociada a Pablo se recoge en los símbolos de la espada y su equivalencia en la lengua, que en síntesis apuntan juntos al ministerio de la predicación (Debió ser Pablo el que se comprometió a favor de la espada / La fe de Pedro es la llave que los protege / Por lo tanto, su lengua corroe / Siente la llave vengada y un

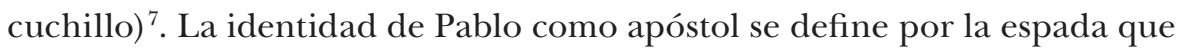
poseía, arma con la que defendió la perfidia judaica; pero al convertirse al cristianismo defendió la Ley Evangélica con la espada espiritual, que es el verbo divino. A través de sus epístolas y predicación Pablo habría extendido por el Mediterráneo el mensaje cristiano en la lengua de los gentiles y códigos de la cultura helena. Finalmente, como ciudadano romano Pablo muere decapitado con una espada por instrucción de Nerón, de modo que el arma representa también su martirio (CarmonaMuela, 2003). La simbología reunida en el epigrama que identifica a Pablo establece en el mismo epigrama un contrapunto con los atributos asignados a Pedro, como el resguardo de la fe, atributos finalmente enaltecidos. El texto sugiere que una vez desaparecido Pablo, era allí en su espada donde estaba su compromiso a favor de la fe, la que fue la llave de Pedro para protegerlos, por tanto, al recoger su lengua afilada se siente más que diez espinas y un cuchillo.

\footnotetext{
6 En la perspectiva de la teorización sobre el emblema hecha por el jurista Andrea Alciato en el siglo XVI, el epigrama es el reverso del emblema si se asume que el emblema son representaciones de objetos que ilustran un concepto mientras que los epigramas son conceptos que ilustran objetos, como obras de arte, ofrendas votivas, tumbas, etc. (Praz, 2005).

7 Que fuerant gladÿ Pauli commissa favori: / En fidei Petrus clave tuetur ea / Ergo hoc, quitentat mordaci carpere Lingua; / Vltricem clavem sentiet, et gladium.
} 
La inscripción del borde inferior está cifrada de manera más compleja que la precedente por cuanto funcionan deliberadamente como acertijo que involucra al mismo Francisco de Ávila. El escrito comienza con un anagrama, texto en el que se modifica la posición de las letras que forman un vocablo creando palabras diferentes. La aproximación literal al enunciado da cuenta de "Francisco de Ávila señor, corazón de los indios, quien fue su mano salvadora" . El segundo texto es presentado bajo el título de Epigramma anagrammicum, una composición poética breve que hace gala de ingenio y a la vez se somete a la alteración de las letras propia de los anagramas. El enunciado está elaborado en primera persona, y se observa la intervención tipográfica al distinguir palabras en mayúsculas y otras en minúscula. El sentido atribuible es: "Señor Francisco de Ávila. Era yo el corazón de los indios, y de los pobres actuales y padre INDIO. Quien fue CORAZÓn y a menudo MANO vida SEGURIDAD" 9

La imagen de Pedro exhibe la potestad divina y humana del apóstol, devenido en obispo al ser elegido por Dios para sustentar a la Iglesia pues se le han revelado las verdades. Entre los dos epigramas se destaca que son los obispos como Pedro y mártires como Pablo quienes definen las verdades para su enseñanza, así como los doctores y confesores que predican, secuencia en la que se incluye el propio doctor Francisco de Ávila.

Para respaldar esta correspondencia entre Pedro, Pablo y el canónigo cuzqueño, Ávila alude en el epigrama inferior que su tarea — por designio divino- de conversión de los gentiles fue el esfuerzo de amor que le valió tornarse en salvador de los indios, replicando la acción de Pablo, Cristo y los mártires. Al reconocer su origen entre los pobres, Ávila manifiesta su humildad, como Pedro y el mismo Cristo. De manera que el discurso visual de Ávila está basado en la definición de las virtudes de Pedro y la equivalencia consigo mismo. Así, el libro cerrado que Pedro acostumbra sujetar en la iconografía católica, y que representa la clave de su misión apostólica, es el símbolo que Ávila introduce en la construcción apostólica y episcopal de sí mismos, y que no es sino la creación de su Tratado de los Evangelios.

La imagen de Pedro penetra en el contenido de los epigramas y lo sintetiza en un episodio clave como es el ascenso del apóstol a la tribuna en 
Antioquía, reconocido como obispo en su saber, y previo a su instalación en Roma como autoridad absoluta de la Iglesia terrenal. La exaltación de la Iglesia secular pudo resolverse en términos visuales con el uso de un escudo u otro símbolo más evidente en su sentido episcopal. Pero la opción por situar al representante eclesiástico supremo en el momento en que se erige por vez primera como obispo, pero con el rostro celestial, es la proyección del propio Francisco de Ávila. A menudo, en la ideación o la traza para el diseño del recurso emblemático intervienen frecuentemente el autor de la obra indicando al maestro grabador lo que desea, según lo documentado para los impresos españoles del siglo XviI, de manera que la fijación del sentido cifrado se ejecuta en el diálogo entre el conjunto del emblema con los paratextos del libro y su contenido.

El emblema del Tratado de los Evangelios paradójicamente alude al poder de manera "clara" y se despliega a su vez en dos planos de sentido complementarios, ambos relacionados con el contexto inmediato del autor en 1645, fecha probable de la composición de la obra (Ávila, 1918). Una apunta hacia la queja velada del canónigo por no recibir aún nombramiento de obispo portando todas las cualidades requeridas para el cargo y para cumplir la función, incluso al mismo nivel que los apóstoles Pablo y Pedro. Los historiadores de la Iglesia peruana colonial que han desarrollado una lectura panegirista de la actuación de Ávila, se han preguntado por las razones que impidieron a la Corona su nombramiento en un obispado, lo que habría sido un rumor a voces en la Lima virreinal de la década de 1630, "violentando el sentido de justicia" al no premiar al notable sacerdote (Urteaga, 1936, p. 169).

El segundo plano del discurso verbo-visual del emblema desplaza el sentido del autoalabanza de Ávila hacia el enaltecimiento del arzobispo de Lima, Pedro de Villagómez, quien es también un Petrus por partida doble: por su rango episcopal y por su nombre. Conseguir el favor del arzobispo de Lima para la elaboración e impresión del Tratado de los Evangelios fue una derrota para Ávila, quien resolvió en el emblema la falta del apoyo episcopal, y en los paratextos del libro al incorporar la carta pastoral de Villagómez sobre la idolatría de los indios. La secuencia apostólica en la que se sitúa Ávila tendría así como predecesor inmediato a Pedro de Villagómez en el encadenamiento de modelos episcopales que comienzan con Pedro y Pablo. De manera que el elogio de las virtudes de Pedro-obispo, como el amor, humildad y pobreza, se proyecta hacia Pedro Villagómez y el mismo Ávila. En el conjunto no hay ningún elemento de la composición que se dirija al rey o al virrey, de manera que Ávila 
se pronuncia en relación con su lugar en el escenario político virreinal a través de la imagen emblemática. Esta se vuelve visible por la palabra evangélica, y juntas ponen en escena el conflicto que anuncia Ávila, es decir, dan lugar al theatrum mundi.

\section{CONCLUSIÓN}

\section{El Hypomnema apologeticum y el Tratado de los Evangelios exponen} la vitalidad y particularidades que adquiere a mediados del siglo XVII el hábito mental emblemático y el arte de la combinatoria en Lima, expresado en la construcción de alegorías visuales que combinaban imágenes provenientes de los textos "almacén" o compilaciones de símbolos, máximas, aforismos, sentencias latinas, epigramas, emblemas y jeroglíficos las que constituyen expresiones ícono-textuales en donde los signos no cumplen funciones estructurales ni fijas (Rodríguez, 1995). La agenda parcialmente visible de ambos letrados se desliza audaz como un mensaje condensado en los conjuntos emblemáticos que funcionan como síntesis mnemotécnica. A través de la literatura emblemática a la que pertenecen las dos anteportadas se insta sutilmente a las autoridades de la monarquía católica a distinguir a cada autor, y así los conjuntos simbólicos irradian su acción más allá de la página que los contiene y se convierten en la clave de lectura de todo el texto. Desde esta perspectiva, el discurso encriptado en imágenes con el que se inicia el Hypomnema apologeticum y el Tratado de los Evangelios, apela a su eficacia como medio de comunicación dentro de la tradición emblemática que hace visible y tangible lo invisible, y como género mixto expresivo-persuasivo, ligado al modo de representación occidental (renacentista italiano, flamenco, barroco español) que adoptaron las élites urbanas de los virreinatos americanos. Como contratantes, exigieron a los artistas y artesanos la aplicación de las convenciones europeas en la producción de las imágenes sueltas y en los textos impresos, lo que supone una práctica cultural que intentó atenuar sin éxito la hibridez o mestizaje, no solo en el uso de ciertas técnicas locales, sino también en el resultado de los productos finales (Gruzinski, 2010).

Las anteportadas del Hypomnema apologeticum y el Tratado de los Evangelios invocan pocos signos para significar mucho como proyectos alegóricos y emblemáticos atípicos y originales, de profundo sentido 
político, que supeditan la exaltación de la Corona a la promoción de sus propios atributos intelectuales y morales individuales, y sugieren su reconocimiento con el nombramiento en la Real Audiencia y en el "obispado celestial de los indios"). De manera plena exhiben la potencialidad del emblema en 1648 como soporte ideológico y vehículo de un mensaje no solo moral, religioso y político, sino también como estrategia de afirmación constitutiva de identidades individuales en los contextos conflictivos que caracterizaron a las sociedades virreinales.

La emblemática y el pensamiento alegórico virreinal se manifiestan triunfales en los dos casos analizados si solo se remite a las condiciones de producción de los conjuntos visuales que finalmente lograron acceder al privilegio de la hoja impresa. Sin embargo, el Hypomnema apologeticum se ha considerado un fracaso en tanto no tuvo la resonancia social de otros alegatos "criollos", como los numerosos polemistas de la Nueva España que respondieron a la epístola del deán alicantino Manuel Martí en el siglo XVIII (Rovira, 1993), quien como Lipsio solo veía indios bárbaros en el Nuevo Mundo. La obra de Diego León Pinelo habría sido un hecho aislado, sin imitadores, seguidores, ni detractores, es decir, habría pasado desapercibida por la vida política y cultural del Virreinato del Perú. Incluso se podría señalar como indicio de su fracaso, que la memoria del Hypomnema apologeticum duró poco pues los defensores de la "identidad criolla” aparecen en el Perú en el siglo siguiente (XviII). Además, solo en tiempos modernos se ha vuelto a estudiar y recordar la obra de León Pinelo, comenzando por Antonello Gerbi en 1945 y después de un largo hiato otras estudiosas e investigadores lo han retomado al final del siglo xx e inicios del xxi (Rose, 1998; Rodríguez, 1992; Cañizares-Esguerra, 1999; Papy, 2001).

Pese a lo anterior, se puede juzgar el éxito del Hypomnema apologeticum, por el hecho de que fue impreso cuatro veces en casi treinta años a contar de su publicación en 1648, dado que la cuarta edición fue en 1671 (Rose, 1998). Las ediciones sucesivas sugieren el interés de una minoría muy activa, que correspondería al colectivo de juristas y oidores sensibles a la defensa del "ingenio indiano", situados a su vez al interior de otra minoría que serían las personas que dominaban el latín y la emblemática en los territorios de la monarquía hispana. Desde este punto de vista, Diego León Pinelo consiguió que el conjunto alegórico de su libro (incluyendo el emblema) fijara certeramente la memoria colectiva de los letrados virreinales aun cuando el autor no accediera al nombramiento en la Real Audiencia, como fue su objetivo con la publicación. 
A diferencia de la obra de León Pinelo, el Tratado de los Evangelios no ha sido estudiado sistemáticamente en el círculo de los especialistas en los Andes centrales y apenas se le menciona en los estudios sobre quechua (Durston, 2007). El grabado de la anteportada ha sido completamente ignorado, incluso para los investigadores que han abordado el prólogo o "Prefación" del sermonario para comprender las tensiones internas de la Iglesia colonial en torno al discurso eclesiástico, el proyecto de evangelización de los indios y el inicio de las campañas de extirpación de idolatrías de 1610 (Duviols, 1977; Estenssoro, 2003; Mac Cormack, 1991; Mills, 1997). En tiempos coloniales el Tratado de los Evangelios fue impreso una única vez, y esa solitaria edición apareció en 1648, al año siguiente de la muerte de Francisco de Ávila, por lo que se trata de una obra póstuma. Al respecto cabe preguntarse si es posible juzgar como una derrota o fracaso que se cumpliera el anhelo del autor fallecido de sacar a la luz su discurso elaborado por fragmentos a lo largo de toda su vida, discurso verbo-icónico que finalmente supera la muerte, la desafía y trasciende en el tiempo. El grabado y emblema del sermonario de Ávila expresan la aspiración del canónigo por la promoción más alta en el escalafón de la Iglesia virreinal como fue convertirse en santo Obispo de Indios, traspasando así los límites del plano de lo terrenal, enlazando con el eterno y procurando así un espacio en la memoria de la Iglesia de Indias y en la historia del difícil devenir de nuestros antecesores los indígenas.

\section{REFERENCIAS}

Acosta, A. (1987). Francisco de Ávila. Cusco 1573(?) - Lima 1647. En G. Taylor, Ritos y tradiciones de Huarochiri del siglo XVII (pp. 553-616). IEP; IFEA.

Ávila, F. (1647). Testamento de Francisco de Ávila. Protocolo notarial de Antonio Hernández de la Cruz, AGN, n. ${ }^{\circ}$ 468, folio 1077.

Ávila, F. (1648). Tratado de los Evangelios. Imprenta de Pedro Cabrera. https:// archive.org/details/tratadodeloseuan00avil

Ávila, F. (1918). Prefación al libro de los Sermones, u homilías en la lengua castellana y la índica general quechua. En H. Urteaga \& C. A Romero., Colección de libros y documentos referentes a la historia del Perú (pp. 57-98). Imprenta Sanmartí.

Burke, P. (2001). Visto y no visto: el uso de la imagen como documento histórico. Crítica.

Burke, P. (2010). Traducciones al latín en la Europa de la época Moderna. En P. Burke \& R. Po-Chia (Eds.), La traducción cultural en la Europa moderna (pp. 7793). Ediciones Akal. 
Cañizares-Esguerra, J. (1999). New World, New Stars: Patriotic Astrology and the Invention of Indian and Creole Bodies in Colonial Spanish America, 1600-1650. American Historical Review, 104(1), 33-68. https://doi.org/10.1086/ ahr/104.1.33

Carmona-Muela, J. (2003). Iconografía de los Santos. Ediciones Akal.

Durston, A. (2007). Pastoral Quechua. The History of Christian Translation in Colonial Peru, 1550-1650. University of Notre Dame Press. https://doi.org/10.2307/j. ctvpg8689

Duviols, P. (1966). Estudio bio-bibliográfico. Francisco de Ávila, extirpador de idolatrías. En J. M. Argüedas \& P. Duviols (Eds.), Dioses y hombres de Huarochiri; narración quechua recogida por Francisco de Ávila (pp. 215-243). Museo Nacional de Historia; Instituto de Estudios Peruanos.

Duviols, P. (1977). La destrucción de las religiones andinas (conquista y colonia). Universidad Autónoma de México.

Eguiguren, L. A. (1949). Semblanza de la Universidad de San Marcos. Talleres de la Empresa Gráfica T. Scheuch.

Estabridis, R. (2002). El grabado en Lima virreinal: documento histórico y artístico (siglos XVI al XIX). Fondo Editorial Universidad Nacional Mayor de San Marcos.

Estenssoro, J. C. (2003). Del paganismo a la santidad. La incorporación de los indios del Perú al catolicismo 1532-1750. Instituto Francés de Estudios Andinos; Pontificia Universidad Católica del Perú. https://doi.org/10.4000/books.ifea.4412

García, J. (2017). Un bestiario para celebrar: fauna simbólica en la fiesta barroca del Virreinato del Perú. Quiroga. Revista de patrimonio iberoamericano, (11), 30-41. https://revistaquiroga.andaluciayamerica.com/index.php/quiroga/ article/view/183

Gerbi, A. (1945). Diego de León Pinelo contra Justo Lipsio. Una de las primeras polémicas sobre el nuevo mundo. Fénix, (2-3), 187-231.

Gisbert, T. (1980). Iconografía y mitos indígenas en el arte. Gisbert y Cía.

Gruzinski, S. (2010). Las cuatro partes del mundo. Historia de una mundialización. Fondo de Cultura Económica.

Gutiérrez, C. M. (2002). Hacia una teoría de la interautorialidad para el Siglo de Oro (ponencia). Actas del VI Congreso de la Asociación Internacional Siglo de Oro. Burgos, España. https://cvc.cervantes.es/literatura/aiso/pdf/06/ aiso_6_2_004.pdf

Hampe, T. (1993). El universo intelectual de un "extirpador de idolatrías": la biblioteca de Francisco de Ávila (1648). Historia y Cultura, 22(1-2), 3-30. https://www.jstor.org/stable/43393091

Kubiak, E. (2008). Grabados de los hermanos Wierix y la pintura Barroca en el Perú y en Polonia (ponencia). xxx Convegno Internazionale di Americanistica. Salerno, Italia.

Ledda, G. (1996). Emblemas y configuraciones emblemáticas en la literatura religiosa y moral del siglo XviI (ponencia). Actas IV de la Asociación Internacional Siglo de Oro (AIso). Alcalá, España. https://cvc.cervantes.es/ literatura/aiso/pdf/04/aiso_4_1_006.pdf 
León, D. (1648). Hypomnema apologeticum pro regali Academia Limensi in Lipsianam periodum. Fondo Antiguo de la Biblioteca de la UsAL. https://archive.org/ details/hypomnemaapolog00lipsgoog/mode/2up

Mac-Cormack, S. (1991). Religion in the Andes. Vision and Imagination in Early Colonial Peru. Princeton University Press.

Martel, J. (1594) Praecepta grammatice ex variis collecta auctoribus. Real Academia de la Historia.

Medina, J. T. (1904). La imprenta en Lima, 1584-1824. Impreso y grabado en la casa del autor. http://www.memoriachilena.cl/archivos2/pdff/mc0008206.pdf

Mills, K. (1997). Idolatry and Its Enemies. Colonial Andean Religion and Extirpation. 1640-1750. Princeton University Press. https://doi. org/10.1515/9780691187334

Minguez, V. (2017). Jeroglíficos para un Imperio. La cultura emblemática en el Virreinato de la Nueva España. Quiroga: Revista de Patrimonio Iberoamericano, (11), 56-68. http://revistaquiroga.andaluciayamerica.com/index.php/ quiroga/article/view/186

Nakládalová, I. (2012). De la varia lección a la encyclopaedia: los ideales de la erudición en la primera Edad Moderna. Studia Aurea: Revista de Literatura Española y Teoría Literaria Del Renacimiento Y Siglo De Oro, (6), 1-29. https://doi. org/10.5565/rev/studiaaurea. 2

Ojeda, A. (2014). Proyecto sobre las fuentes grabadas del arte colonial (PESSCA). PUCP.

Papy, J. (2001). La profecía de Lipsio sobre el Nuevo Mundo y el desarrollo de una identidad "americana" en la Universidad de Lima. En E. González \& L. Pérez (Eds.), Colegios y universidades: del antiguo régimen al liberalismo (pp. 255-283). UNAM.

Pardo, T. (1990). Impresos peruanos del siglo xvi: ornamentación, tipografía y encuadernación. Boletín Instituto Riva Agüero, (17), 207-267. https://tinyurl. com/yywfkykv

Pope-Hannessy, J. (1985). El retrato en el Renacimiento. Ediciones Akal.

Praz, M. (2005). Imágenes del Barroco: estudios de emblemática. Ediciones Siruela.

Ramos, G. (1988). El Tribunal de la Inquisición en el Perú, 1605-1666. Un estudio social. Cuadernos para la historia de la evangelización en América Latina III, (3), 93-127.

Reyes, F. (2010). La estructura formal del libro antiguo español. Paratesto (7), 9-59. https://doi.org/10.1400/150386

Rodríguez, F. (1995). Emblemas. Lecturas de la imagen simbólica. Alianza.

Rodríguez, A. (1992). Diego de León Pinedo, universitario de Salamanca y de San Marcos de Lima. Historia de la Educación. Revista interuniversitaria, (11), 49-72. http://hdl.handle.net/10366/136348

Rose, S. V. (1998). Un caso particular de la recepción de Justo Lipsio en el Perú: El Hypomnema Apologeticum de Diego de León Pinelo (1648). En M. BlancoMorel, \& M. Piejus (Eds.), Les Flandres et la culture espagnole et italienne aux XvIe et XVIIe siècles (pp. 251-265). Université Lille. 
Rovira, J. (1993). Para una revisión de la polémica mexicana dieciochesca con Manuel Martí, deán de Alicante. Sharq Al-Andalus: Estudios mudéjares y moriscos, (10), 607-636. https://doi.org/10.14198/ShAnd.1993-1994.10-11.36

Stastny, F. (1984). La universidad como claustro, vergel y árbol de la ciencia. Una invención iconográfica en la Universidad del Cuzco. Anthropológica, 2(2), 105-167.

Tardieu, J. P. (1995). L'Inquisition de Lima et les hérétiques étrangers (XVI-XVII siécles). L'Harmmattan.

Urteaga, H. (1936). Doctor Francisco de Ávila. Revista del Archivo Nacional del Perú, 9(2), 169-175. 